\title{
A INFÂNCIA NAS CANÇÕES DE CHICO BUARQUE: DA FANTASIA AO ABANDONO
}

\author{
The childhood in the songs of Chico Buarque: from fantasy to abandonment
}

\author{
Luciano Dias Cavalcanti* \\ Universidade Vale do Rio Verde
}

\begin{abstract}
Resumo: O cancioneiro de Chico Buarque apresenta um número considerável de canções que tratam do universo infantil, material ainda pouco estudado de maneira sistemática pela fortuna crítica do compositor. Nossos esforços, nesse artigo, serão direcionados para a análise das duas proposições frequentes na obra do compositor, no que diz respeito à presença da infância em sua obra. No primeiro caso, há uma forte marca do universo da fantasia e do sonho, no qual a infância é vista como um locus amoenus, uma espécie de paraíso perdido. Em contraste à esta proposição, nota-se na obra do compositor a presença da infância por meio dos seus infortúnios, a pobreza e o abandono. Correspondendo à primeira perspectiva, serão analisadas as letras das canções "Até pensei”; "João e Maria"; "Maninha"; "Doze anos"; "Massarandupió". No segundo caso, nossa análise se voltará para as imagens infantis construídas em "Pivete"; "O meu guri"; "Minha história"; "Brejo da cruz" e "Carioca".
\end{abstract}

Palavras-chave: Chico Buarque. Infância. Fantasia. Abandono.

\begin{abstract}
The songbook of Chico Buarque presents a considerable number of songs that deal with children's universe, material yet little studied in a systematic way by fortune critique of composer. Our efforts, for this article, will be directed to the analysis of the two frequent propositions in the work of the composer, as regards the presence of childhood in your work. In the first case there is a strong brand in the universe of fantasy and dream, in which childhood is seen as a locus amoenus, a kind of paradise lost. In contrast to this proposition is noted in the work of this composer from childhood through his misfortunes, poverty and abandonment. Corresponding to the first perspective, will be reviewed the lyrics of songs "Até pensei"; "João e Maria"; "Maninha"; "Doze anos"; "Massarandupió". In the second case, our analysis will turn to the children's images built in "Pivete"; "O meu guri"; "Minha história"; "Brejo da cruz" e "Carioca".
\end{abstract}

Keywords: Chico Buarque. Childhood. Fantasy. Abandonment.

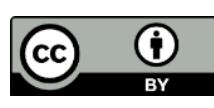

Esta obra está licenciada sob uma Creative Commons - Atribuição 4.0

\footnotetext{
* Doutor em Teoria e História Literária pelo IEL/UNICAMP. Realizou estágio de pós-doutorado no Departamento de Literatura Brasileira da UNESP/Araraquara. É professor de Teoria Literária e Literatura Brasileira no Mestrado em Letras da Universidade Vale do Rio Verde (UninCor) e pesquisador do grupo de pesquisa Minas Gerais: Diálogos (cadastrado no Diretório de Grupos de Pesquisa do CNPq). E-mail: bavarov@terra.com.br.

(iD https://orcid.org/0000-0002-3990-1493
}

Anu. Lit., Florianópolis, v. 23, n. 2, p. 46-66, 2018. ISSNe 2175-7917 
Recebido em: 01/06/2018

Aceito em: 15/08/2018

\title{
Introdução
}

O cancioneiro de Chico Buarque apresenta um número considerável de canções que tratam do universo infantil, material ainda pouco estudado de maneira sistemática pela fortuna crítica do compositor. Além de suas composições musicais, o autor chegou, nos anos 1970, a adaptar Os Saltimbancos, musical de Sérgio Bardotti e Luis Enríquez Bacalov, inspirado em Os músicos de Bremen, dos irmãos Grimm; escreveu um livro destinado ao público infantil Chapeuzinho Amarelo, referência direta ao conto de fadas Chapeuzinho vermelho. Compôs também, junto com Edu Lobo, o musical infantil $O$ grande circo místico, baseado no poema homônimo de Jorge de Lima.

No âmbito de seu repertório autoral, que nos interessa em particular nesse artigo, é possível, em muitas de suas composições, vislumbrar o universo infantil. Nossos esforços, nesse artigo, se constituirão na análise de duas proposições frequentes de seu repertório, no que diz respeito à presença da infância em sua obra discográfica. No primeiro caso, iremos nos atentar à forte marca do universo da fantasia e do sonho, no qual a infância é vista como um locus amoenus, uma espécie de paraíso perdido. Em contraste à esta proposição, notamos, na obra de Chico Buarque, o comparecimento da infância por meio dos seus infortúnios: a pobreza e o abandono.

O que observamos na obra do compositor é a negação, com extrema sensibilidade poética, de uma concepção que considera a criança um modelo reduzido do homem, que deve ser ajustado o mais rápido possível às normas do mundo adulto. Muito pelo contrário, Chico Buarque valorizará a criança e o seu mundo e a utilizará como matéria, com sua multiplicidade de possibilidades imaginativas, como parte integrante da construção de suas composições musicais, enriquecendo liricamente seus trabalhos a partir de elementos retirados do mundo infantil.

\section{A fantasia e sonho}

No que diz respeito à presença da infância representada em seu aspecto lúdico e feliz na obra de Chico Buarque, a canção "Até pensei”, do álbum Chico Buarque de Hollanda - volume III, de 1968 é exemplar:

\author{
Junto à minha rua havia um bosque \\ Que um muro alto proibia \\ Lá todo balão caía \\ Toda maçã nascia \\ E o dono do bosque nem via \\ Do lado de lá tanta aventura \\ E eu a espreitar na noite escura \\ A dedilhar esta modinha \\ A felicidade
}




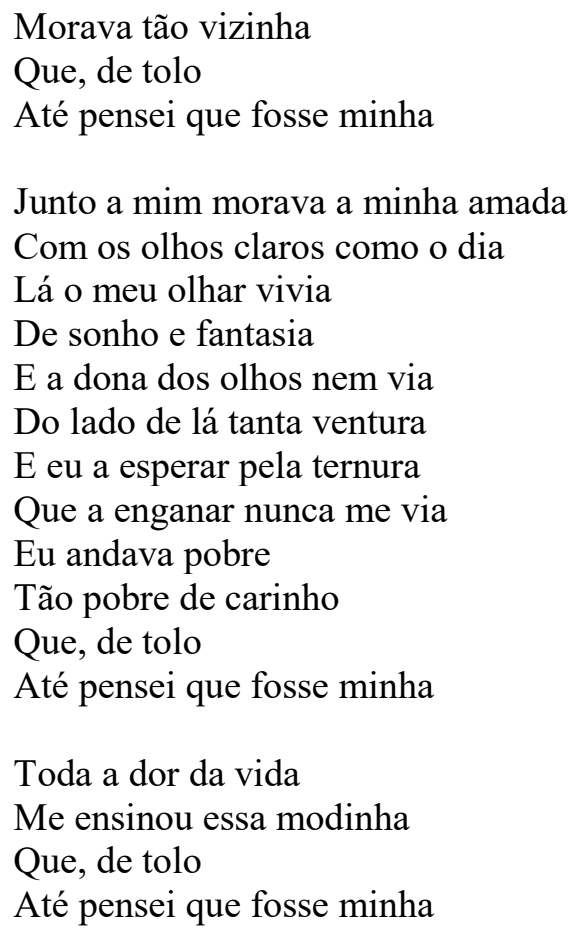

Esta canção de Chico Buarque rememora um tempo passado em tom de nostalgia. O olhar lançado ao passado é o olhar do adulto que visualiza a infância perdida, em que a interdição ("Que um muro alto proibia") exerce um fascínio. A magia do que poderia existir "do lado de lá" brota da imaginação do compositor e transforma-se em "modinha".

Além da divisão espacial feita pelo "muro alto", há a divisão temporal que revela dois tempos distintos: o da infância, marcada pelos verbos no passado ("havia", "proibia", "caía", "nascia", etc.), e o da idade adulta, caracterizada pelo julgamento com que o sujeito lírico olha para o passado ("Que, de tolo/ Até pensei que fosse minha").

A primeira estrofe da canção mostra o ambiente real misturado ao espaço mágico da infância, no qual o menino vê o bosque, elemento constantemente presente nos contos de fadas infantis, cercado por um muro que impede sua entrada num mundo mágico, onde haverá "tanta ternura" e "Lá todo balão caía/ E o dono do bosque nem via". Neste momento, podemos notar a indiferença do mundo adulto às aventuras imaginosas da infância ("E o dono do bosque nem via"). Na segunda estrofe, a canção passa do discurso puramente infantil para o amoroso. A infância dá lugar à tentativa da realização amorosa transfigurada na imagem da amada de "olhos claros como o dia" em que o olhar enamorado vivia de sonho e fantasia. Na impossibilidade da realização amorosa, o enamorado consciente vê que somente na infância poderia realmente ser feliz, pois, no decorrer do tempo, o crescimento e a perda da infância ensinam, pelas experiências vividas, que a felicidade já não mais existe, como podemos notar nos versos "Toda a dor da vida/ me ensinou essa modinha". Trata-se de uma modinha melancólica que vê a possibilidade da felicidade somente no mundo infantil. Para Adélia Bezerra de Menezes, um número grande de canções de Chico Buarque, compostas nesse momento histórico (19601970), revela um tom nostálgico, uma busca pelo primitivo, pelo ingênuo, uma negação do consumismo e da massificação, significando, assim, "uma recusa do mundo industrializado: é 
também uma forma de poesia de resistência. Mas ao mesmo tempo, há a consciência de que esse primitivo está perdido para sempre.” (MENEZES, 1982, p. 48, grifos da autora).

Algumas canções, centrando-se nessa temática, revelam de maneira intensamente poética como o período da infância está presente de forma marcante no inconsciente do compositor. Além de "Até pensei”, outras canções de Chico Buarque rememoram com nostalgia a infância perdida, como, por exemplo, "João e Maria”, gravada no álbum Os meus amigos são um barato, de Nara Leão, de 1977.

Agora eu era o herói

E o meu cavalo só falava inglês

E a noiva do cowboy

Era você

Além das outras três

Eu enfrentava os batalhões

Os alemães e seus canhões

Guardava o meu bodoque

E ensaiava um rock

Para as matinês

Agora eu era o rei

Era o bedel e era também juiz

E pela minha lei

A gente era obrigado a ser feliz

E você era a princesa

Que eu fui coroar

E era tão linda de se admirar

Que andava nua pelo meu pais

Não, não fuja não

Finja que agora eu era o seu brinquedo

Eu era o seu pião

O seu bicho preferido

Sim, me dê a mão

A gente agora já não tinha medo

No tempo da maldade acho que a gente nem tinha nascido.

Agora era fatal

Que o faz-de-conta terminasse assim

Prá lá deste quintal

Era uma noite que não tem mais fim

Pois você sumiu no mundo

Sem me avisar

E agora eu era um louco a perguntar

O que é que a vida vai fazer de mim.

A canção "João e Maria”, parceria de Chico com Sivuca, se constrói a partir de uma linguagem infantil que nos faz rememorar as brincadeiras do faz-de-conta que compõem o mundo da criança. Nesse caso, é possível pensar em uma relação entre a criação poética e o mundo infantil, a partir das considerações de Freud. No ensaio "O poeta e o fantasiar", publicado em 1908, resultado de uma conferência feita em dezembro de 1907 endereçada a um 
público de Letras, Freud considera que os primeiros traços da atividade literária se encontram na infância:

Não deveríamos procurar os primeiros indícios da atividade poética já nas crianças? A atividade que mais agrada e a mais intensa das crianças é brincar. Talvez devêssemos dizer: toda criança brincando se comporta como um poeta, na medida que ela cria seu próprio mundo, melhor dizendo, transpõe as coisas do seu mundo para uma nova ordem, que lhes agrada." (FREUD, 2015, p. 54).

No ato de brincar com as palavras, como fazem as crianças, o poeta, de alguma maneira, retornaria à sua infância. Nesse sentido, o processo da criação literária pertenceria ao mesmo campo da atividade imaginativa, com ênfase no sonho diurno e suas vinculações com a brincadeira infantil:

O poeta faz algo semelhante à criança que brinca; ela cria um mundo de fantasia que leva à sério, ou seja, um mundo formado por grande mobilização afetiva, na medida em que se distingue rigidamente da realidade. E a linguagem mantém esta afinidade entre a brincadeira infantil e a criação poética, na medida em que a disciplina do poeta, que necessita do empréstimo de objetos concretos passíveis de representação, é caracterizada como brincadeira/jogo [Spiele]: comédia [Lustspiel], tragédia [Trauerspieler] e as pessoas que as representam, como atores [Schauspieler]. (FREUD, 2015, p. $54)$.

Tal perspectiva é percebida, em “João e Maria”, não só por meio da expressão "Agora eu era”, indicativa do início da história fantasiosa construída pela/para a criança, mas também pela troca de papéis assumidos pelas personagens no jogo lúdico infantil: "herói"; "noiva do cowboy", "rei”; “juiz”; "princesa”, etc. Nesse sentido, Fontes aponta que a posição temporal presente "Agora eu era" resgata uma expressão verdadeira do imaginário infantil, que nos revela o ato consciente de deixar a realidade e penetrar na fantasia.

O "era”, tão comum na ilusão criada pela criança, remonta ao "era uma vez", expressão que dá início ao mundo maravilhoso dos contos de fadas e das aventuras heroicas. $\mathrm{O}$ estranhamento que passa existir na estrutura "Agora eu era" justifica-se, portanto, no nonsense criado a partir da imaginação. Há uma cisão temporal que corresponde à cisão da realidade/fantasia. $\mathrm{O}$ "agora" revela a consciência de que, terminada a imaginação, volta a realidade do "antes". (FONTES, 1999, p. 121, grifos da autora)

Nesta canção, podemos perceber que o seu lirismo é construído a partir dos elementos imaginativos do mundo infantil. Podemos dizer que esta canção se divide em três momentos: a infância, a adolescência e o mundo adulto, nos quais podemos notar, em seu primeiro momento, a imagem heroica construída pelo imaginário infantil, na qual o herói montado no seu cavalo (que falava inglês) enfrenta os alemães com seus canhões.

No segundo momento da canção, é o adolescente que assume o discurso poético. A criança "guarda o bodoque" para que o adolescente possa ensaiar um rock para as matinês. O terceiro momento é representativo do mundo adulto, que se revela presente na canção com a 
perspectiva de "coroar" a princesa tão linda que andava nua no seu país.

No término da canção, podemos ver claramente que o mundo imaginativo da infância é perdido e valorizado ao mesmo tempo, como bem podemos perceber nos seguintes versos: "Agora era fatal/ Que o faz de conta terminasse assim/ Pra lá deste quintal/ era uma noite que não tem mais fim." Esses versos nos remetem à vida infantil "do quintal", local, num passado não muito distante, comumente frequentado pelas crianças e utilizados como ambiente para as brincadeiras das mais variadas espécies, sempre lúdicas e imaginosas. Enfim, um local onde o mundo é perfeito e no qual só pode haver felicidade.

Este ambiente infantil é contraposto ao mundo adulto problemático e racional, por natureza, onde não há lugar para a fantasia e a felicidade, como podemos observar na metáfora dos versos "prá lá deste quintal/ Era uma noite que não tem mais fim". O que quer dizer que fora da infância, da imaginação ou do mundo lúdico não existe possibilidade de ser feliz.

Outra canção de Chico Buarque que também rememora o tempo da infância com nostalgia é "Maninha", gravada no álbum Miúcha e Antônio Carlos Jobim, de Miúcha e Tom Jobim, de 1977.

Se lembra da fogueira

Se lembra dos balões

Se lembra dos luares dos sertões

A roupa no varal

Feriado nacional

E as estrelas salpicadas nas canções

Se lembra quando toda modinha

Falava de amor

Pois nunca mais cantei, ó maninha

Depois que ele chegou

Se lembra da jaqueira

A fruta no capim

O sonho que você contou pra mim

Os passos no porão

Lembra da assombração

E das almas com perfume de jasmim

Se lembra do jardim, ó maninha

Coberto de flor

Pois hoje só dá erva daninha

No chão que ele pisou

Se lembra do futuro

Que a gente combinou

Eu era tão criança e ainda sou

Querendo acreditar

Que o dia vai raiar

Só porque uma cantiga anunciou

Mas não me deixe assim, tão sozinho

A me torturar

Que um dia ele vai embora, maninha

Pra nunca mais voltar 
Em "Maninha", ao recordar as figuras da infância, o eu lírico construído pelo compositor evoca fragmentos de canções caras à sensibilidade brasileira, tais como "Luar do sertão" (Catulo da Paixão cearense) e "Chão de estrelas" (Orestes Barbosa e Sílvio Caldas), como podemos ver nos primeiros versos da canção. O espaço do quintal está novamente presente nesta canção de Chico, aludindo, como "João e Maria", à infância. Os elementos "fogueira", "balões", "luares do sertão", "feriado nacional" nos remetem também às festas de São João como uma visão do folclore brasileiro que sobrevive nas reminiscências do eu lírico.

Nessa canção, o período da infância, novamente lembrado com nostalgia, é visto como um tempo bom e passado, "Se lembra quanto toda modinha/ falava de amor", em que não era preciso cantar músicas de protesto (que sempre são atribuídas ao compositor), mas somente modinhas de amor; aqui, silenciadas pela presença de um "ele", que sugere uma autoridade repressora. (CARVALHO, 1984, p. 67). Quem fala nesta canção é um adulto, já que todo o discurso é construído no passado (enfatizado pela repetição da expressão "Se lembra" em todo o texto) e marcado por um "ele" indeterminado e ruim, representando o momento presente, como observamos nos versos "Pois nunca mais cantei, ó maninha/ Depois que ele chegou"; "Pois hoje só dá erva daninha/ no chão que ele pisou". ${ }^{1}$

De acordo com Fontes (1999, p. 123), a canção passa, na segunda estrofe, de elementos memorialísticos, guardados em sua lembrança e rememorados através dos vários sentidos, como o visual, presentes no verso, "A fruta no capim"; o auditivo, "Os passos no porão" e o olfativo, "E das almas com perfume de jasmim", misturados às fantasias infantis como podemos ver no verso, "Os passos no porão", sugerindo o medo da assombração comum ao imaginário infantil.

No entanto, a última estrofe da canção, apesar do tempo presente/do tempo adulto, apresenta a esperança de que ainda possa haver um tempo feliz como o da infância: "Eu era criança e ainda sou/ Querendo acreditar/ Que o dia vai raiar/ Só porque uma cantiga anunciou”). Subiste, assim, no eu lírico, a esperança de "Que um dia ele vai embora, maninha/ Pra nunca mais voltar".

Na canção "Doze anos", do álbum Ópera do Malandro, de 1979, Chico Buarque faz um diálogo intertextual com o poema "Meus oito anos", do poeta romântico Casimiro de Abreu, a partir da "retomada" de alguns versos do poema:

Oh! que saudades que tenho

Da aurora da minha vida,

Da minha infância querida

Que os anos não trazem mais!

Que amor, que sonho, que flores,

\footnotetext{
${ }^{1}$ Wagner Homem conta em seu livro, Histórias de canções - Chico Buarque, que: "Chico diz que ["Maninha"] é uma canção disfarçada de delicadeza, falando de uma infância imaginária. [...] O hábito, desenvolvido nos anos mais cruéis da ditadura, de ler nas entrelinhas, fazia com que as pessoas especulassem sobre quem era esse 'ele' de 'depois que ele chegou'. Até Tom Jobim brincava dizendo: 'Ele! Ele! Ele é o general”. Embora a canção tenha sido composta para sua irmã Miúcha gravar, Chico assegura que a 'maninha' da letra nada tem a ver com a irmã, mas sim com a forma de tratamento carinhosa, assim como 'iaiá' ou 'querida'”. (HOMEM, 2009, p. 161). Tal afirmativa de Chico reforça o status de construção poética de seu texto, concebido como da ordem da imaginação.
}

Anu. Lit., Florianópolis, v. 23, n. 2, p. 46-66, 2018. ISSNe 2175-7917 
Naquelas tardes fagueiras,

À sombra das bananeiras,

Debaixo dos laranjais!

[...] (ABREU apud CANDIDO; CASTELO, 1991, p. 245)

Vejamos a letra da canção de Chico:

Ai, que saudades que eu tenho

Dos meus doze anos

Que saudade ingrata

Dar banda por ai

Fazendo grandes planos

E chutando lata

Trocando figurinha

Matando passarinho

Colecionando minhoca

Jogando muito botão

Rodopiando pião

Fazendo troca-troca

Ai que saudades que eu tenho

Duma travessura

O futebol de rua

Sair pulando muro

Olhando a fechadura

E vendo mulher nua

Comendo fruta no pé

Chupando picolé

Pé-de-moleque, paçoca

$\mathrm{E}$, disputando troféu

Guerra de pipa no céu

Concurso de piroca

É visível nos dois textos um saudosismo do tempo da infância/adolescência. O que difere a composição de Chico (uma paródia) do poema de Casimiro é que, diferente do poeta romântico que representa uma infância ingênua; o vocabulário de "Doze anos" ressalta a malícia da adolescência do tempo moderno ("Fazendo troca-troca"; "Olhando fechadura / E vendo mulher nua"; "Concurso de piroca") e uma relação um tanto degradadora da natureza ("Matando passarinho / Colecionando minhoca").

É possível relacionar esta canção (como todas as outras, principalmente devido à cristalização da ideia de que Chico é essencialmente um compositor engajado politicamente) ${ }^{2}$ ao contexto histórico da época de sua composição, a ditadura militar. Nessa perspectiva, o compositor utilizar-se-ia de uma paródia para driblar a repressão da ditadura e falar da saudade de um tempo livre, sem censura. Esse deslocamento temporal de uma realidade opressora para

\footnotetext{
${ }^{2}$ No livro Música Popular Brasileira e Poesia: a valorização do "pequeno" em Chico Buarque e Manuel Bandeira, há uma comparação entre o poeta músico (Manuel Bandeira) e o músico poeta (Chico Buarque) no sentido de esclarecer esse pretenso engajamento do compositor, evidenciando o seu lirismo. Não se nega as várias leituras das canções de Chico Buarque, inclusive a política, que realmente pode ser feita, mesmo que o compositor sempre negue esse tipo de interpretação unilateral de suas composições. Na obra musical de Chico Buarque o lírico e o político andam juntos, e Chico Buarque não é um compositor exclusivamente engajado. (CAVALCANTI, 2007).
}

Anu. Lit., Florianópolis, v. 23, n. 2, p. 46-66, 2018. ISSNe 2175-7917 
uma realidade libertadora da infância imaginária revela a rejeição do tempo presente opressor.

Essa presença da infância na lírica como forma de rememoração acontece, de acordo com Alfredo Bosi, como "resposta ao ingrato presente":

[...] é, na poesia mítica, a ressacralização da memória mais profunda da comunidade. E quando a mitologia de base tradicional falha, ou de algum modo já não entra nesse projeto de recusa, é sempre possível sondar e remexer as camadas da psique individual. A poesia trabalhará, então, a linguagem da infância recalcada, a metáfora do desejo, o texto do Inconsciente, a grafia do sonho: [...] A poesia recompõe cada vez mais arduamente o universo mágico que os novos tempos renegam. (BOSI, 1977, p. 150).

Dessa maneira, o ambiente e a mitologia utilizados pelo compositor são aqueles provindos das figuras da infância ou da tradição popular. Para Bosi, "a memória, como forma de pensamento concreto e unitivo, é o impulso primeiro e recorrente da atividade poética. Ninguém se admire se a elas voltarem os poetas como defesa e resposta ao 'desencantamento do mundo' que, na interpretação de Max Weber, tem marcado a história de todas as sociedades capitalistas, [...]”. (BOSI, 1977, p. 152-153).

A propósito dessa rememoração como negação do presente, Bosi observa que a saudade de um tempo bom nunca é reacionária; reacionária é a "justificação" do mal em qualquer tempo ou o olhar conivente com a opressão:

[...] $\operatorname{Re}($ cor $)$ dar a natureza é, etimologicamente, repô-la no coração do homem, socializando-a no mesmo passo em que o homem se naturaliza. A poesia que busca dizer a idade de ouro e o paraíso perdido acaba exercendo um papel humanizador das carências primárias do corpo: a comida, o calor, o sono, o amor.

A consciência que se volta, respeitosa e atenta, para o que não é ainda consciência - a pedra, a planta, o bicho, a infância - está prestes a cumprir a síntese entranhadamente poética do sujeito e o objeto que se chama conceito concreto. [...]

Reinventar imagens da unidade perdida, eis o modo que a poesia do mito e do sonho encontrou para resistir à dor das contradições que a consciência vigilante não pode deixar de ver. (BOSI, 1977, p. 154-155).

À canção "Doze anos", se considerarmos uma perspectiva um tanto participante do compositor, poderíamos associar a "Acalanto", do álbum Construção (1971), na qual Chico Buarque, por meio de um sujeito poético, canta a uma criança para que ela durma e/ou continue em sono para que não vislumbre o tempo hodierno:

Dorme minha pequena

Não vale a pena despertar

Eu vou sair

Por aí afora

Atrás da aurora

Mais serena

Com seu neto Chico Brown, responsável pela melodia, Chico Buarque compôs a letra

Anu. Lit., Florianópolis, v. 23, n. 2, p. 46-66, 2018. ISSNe 2175-7917 
de Massarandupió, do álbum Caravanas, de 2017.

No mundaréu de areia à beira-mar

De Massarandupió

Em volta da massaranduba-mor

De Massarandupió

Aquele piá

Aquele neguinho

Aquele psiu

Um bacuri ali sozinho

Caminha

Ali onde ninguém espia

Ali onde a perna bambeia

Ali onde não há caminho

Lembrar a meninice é como ir

Cavucando de sol a sol

Atrás do anel de pedra cor de areia

Em Massarandupió

Cavuca daqui

Cavuca de lá

Cavuca com fé

Oh, São Longuinho

Oh, São Longuinho

Quem sabe

De noite o vento varre a praia

Arrasta a saia pela areia

E sobe num redemoinho

É o xuá

Das ondas a se repetir

Como é que eu vou saber dormir

Longe do mar

Ó mãe, pergunte ao pai

Quando ele vai soltar a minha mão

Onde é que o chão acaba

E principia toda a arrebentação

Devia o tempo de criança ir se

Arrastando até escoar, pó a pó

Num relógio de areia o areal de

Massarandupió

Por meio de jogos verbais e de aliterações (“pió, piá, psiu”), Chico Buarque torna conhecidas as experiências da meninice do neto, de uma infância vivida em meio à natureza (praia, areia, mar) e música. Novamente, Chico busca formatar seus versos por meio da linguagem infantil, usando a repetição paralelística como forma (na primeira estrofe da canção):

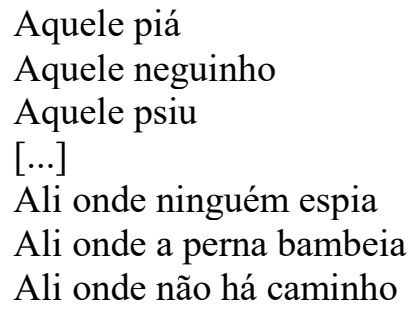


$[\ldots]$

Cavuca daqui

Cavuca de lá

Cavuca com fé

A infância é descrita pelo eu lírico a partir do desejo de continuidade sem fim, por meio da metáfora da ampulheta do relógio: "Devia o tempo de criança ir se / arrastando até escoar, pó a pó / Num relógio de areia o areal de / Massarandupió." No entanto, a canção chega ao fim assim como tempo da infância se acaba: "Ó mãe, pergunte ao pai/ quando ele vai soltar a minha mão / Onde é que o chão acaba / E principia toda a arrebentação".

\section{A pobreza e o abandono}

Outra importante relação de Chico Buarque com o tema da infância pode ser vista na "emoção social” de várias de suas composições. O compositor irá relacionar o tema da infância à questão da pobreza e do abandono em que muitas crianças se encontram em nosso país. Vejamos como isso ocorre em "Pivete", do álbum Chico Buarque, de 1978:

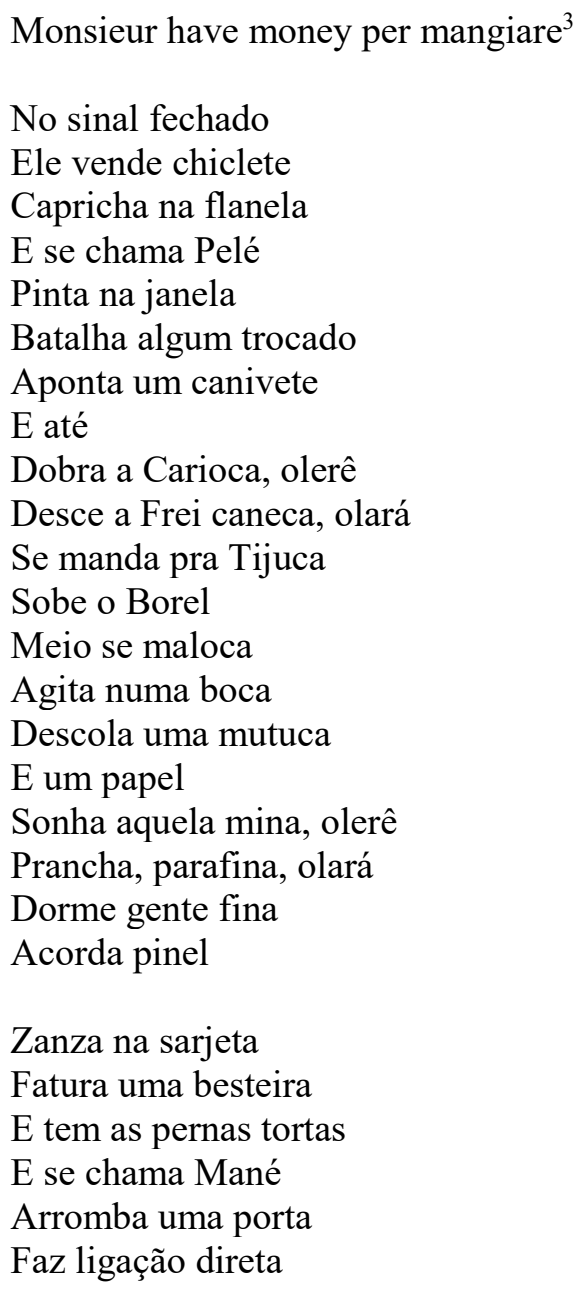

\footnotetext{
${ }^{3}$ Wagner Homem conta "lendo uma reportagem sobre meninos da Candelária, que mendigam num idioma que mistura várias línguas, Chico decidiu incluir a frase 'Monsieur have money per mangiare' na regravação que fez em 1990. Em 23 de julho de 1993, oito de seus 'pequenos parceiros' foram barbaramente assassinados no episódio conhecido como Chacina da Candelária”. (HOMEM, 2009, p. 173).
} 
Engata uma primeira

E até

Dobra a Carioca, olerê

Desce a Frei Caneca, olará

Se manda pra Tijuca

Na contramão

Dança pára-lama

Já era pára-choque

Agora se chama

Emersão

Sobe no passeio, olerê

Pega no Recreio, olará

Não se liga em freio

Nem direção

No sinal fechado

Ele transa chiclete

E se chama pivete

E pinta na janela

Capricha na flanela

Descola uma bereta

Batalha na sarjeta

E tem as pernas tortas

"Pivete", nome coloquial ou gíria utilizada para designar o menino de rua, dá o título à canção, na qual vemos descrita a vida de um menor abandonado. No início da canção, os meninos saem de casa para, no sinal fechado, venderem chicletes e limparem ou cuidarem de carros, generalizados pelo nome "Pelé" - que, entre nós, é costume chamar qualquer menino ou qualquer pessoa negra por analogia ao nosso grande jogador de futebol. A partir da saída de casa, a criança está sujeita a todas consequências provindas de sua inserção na metrópole. $\mathrm{O}$ pivete, que anteriormente trabalha para conseguir dinheiro, se arma com um canivete e passa a assaltar os transeuntes. $\mathrm{O}$ menino que ia para rua trabalhar se transforma em um bandido, um pequeno assaltante, para conseguir dinheiro para comprar maconha e cocaína no Morro do Borel. Após usufruir dos prazeres propiciados pela droga, (uma espécie de anestésico do cotidiano duro e massacrante no qual a criança transformada em adolescente vive), o menino pode sonhar com uma garota, com a vida na praia como os surfistas. Com o êxtase da droga dorme bem, "gente fina"; após seu feito, acorda mal, "pinel".

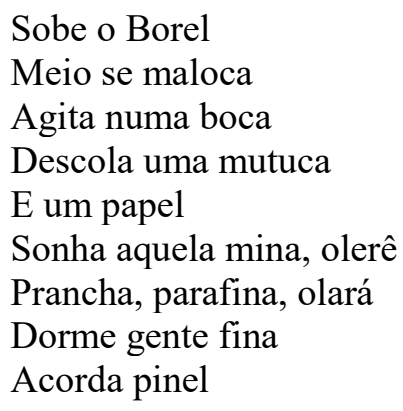

Após acordar, o pivete tem que retornar à sua vida real e, como uma espécie de eterno retorno, tem que conseguir sobreviver através de seus furtos, progressivamente. Novamente,

Anu. Lit., Florianópolis, v. 23, n. 2, p. 46-66, 2018. ISSNe 2175-7917 
ele é relacionado a outro grande jogador de futebol brasileiro, Mané Garrincha, sugerindo que uma possível habilidade do menino é desperdiçada pela falta de condições para desenvolver seu talento para o esporte - aqui especificamente o futebol. Essa energia é canalizada para o crime.

Os roubos progressivamente mais violentos são relacionados ao crescimento do pivete, que não é ainda um adulto - é o caso de se perguntar como uma criança envolvida neste contexto de marginalidade e subnutrição conseguiria chegar à idade adulta. Mas com uma vida tão intensa - agindo como um adulto que tem que se sustentar - há o amadurecimento acelerado. O pivete transforma-se em um bandido profissional, rouba carros e se chama "Emersão", aumentativo de Emerson - alusão ao automobilista Emerson Fittipaldi e também uma possível transformação deste nome próprio pelo linguajar popular. Sem direção certa tanto na vida quanto nas ruas, ele está perdido. Segue diversas ruas do Rio de Janeiro sem freio e direção: "Não se liga em freio / Nem direção". Assim se constitui a vida da criança de rua, numa progressão de papéis que vai do vendedor de chiclete ao flanelinha, do trombadinha ao bandido, construído por meio de uma situação de vulnerabilidade e abandono sociais.

Outra canção de Chico que trata do mesmo tema de "Pivete" é "O meu guri", do álbum Almanaque, de 1981. Nessa canção, no entanto, a condição precária do pivete ou do menino de rua chega ao extremo, isto é, à morte. Nesse caso, "O meu guri” pode ser lida como uma canção que completa o ciclo de "Pivete", que leva o menor de rua a seu abandono maior, a morte.

Quando, seu moço, nasceu meu rebento

Não era o momento dele rebentar

Já foi nascendo com cara de fome

E eu não tinha nem nome pra lhe dar

Como fui levando, não sei the explicar

Fui assim levando ele a me levar

E na sua meninice ele um dia me disse

Que chegava lá

Olha aí

Olha aí

Olha aí, é o meu guri, olha aí

Olha aí, é o meu guri

E ele chega

Chega suando e veloz do batente

E traz sempre um presente pra me encabular

Tanta corrente de ouro, seu moço

Que haja pescoço pra enfiar

Me trouxe uma bolsa já com tudo dentro

Chave, caderneta, terço e patuá

Um lenço e uma penca de documentos

Pra finalmente eu me identificar, olha aí

Olha aí, é o meu guri

Ele chega

Chega no morro com o carregamento

Pulseira, cimento, relógio, pneu, gravador

Rezo até ele chegar cá no alto

Essa onda de assalto tá um horror 
Eu consolo ele, ele me consola

Boto ele no colo pra ele me ninar

De repente acordo, olho pro lado

E o danado já foi trabalhar, olha aí

Olha aí, ai o meu guri, olha aí

Olha aí, é o meu guri

E ele chega

Chega estampado, manchete, retrato

Com venda nos olhos, legenda e as iniciais

Eu não entendo essa gente, seu moço

Fazendo alvoroço demais

O guri no mato, acho que tá rindo

Acho que tá lindo de papo pro ar

Desde o começo, eu não disse, seu moço

Ele disse que chegava lá

Olha aí, ai o meu guri, olha aí

Olha aí, é o meu guri

"O meu guri", como "Pivete", narra a "história" de um menino que vive de expedientes ilícitos. No entanto, a primeira se distingue da segunda por haver uma relação familiar entre o menino e sua mãe, relação que comumente não costuma existir entre menores infratores que vivem pelas ruas. Se em "Pivete", o abandono era também familiar; aqui, há a encenação de uma família carente, representada pela figura materna, já na primeira estrofe da canção: o guri nasce prematuro, passa fome e sem identidade e sem filiação paterna.

O garoto desce o Morro para ir à cidade para roubar e sustentar a família, formada apenas por ele e pela mãe. O sujeito lírico da canção é a mãe do garoto, figura tão marginalizada e desamparada quanto a criança. Para Menezes, a canção Chico "desvenda o desamparo feminino e a procura de proteção que, paradoxalmente, por vezes, a maternidade mascara [...] E mostra igualmente, com insistência, o engano materno relativamente às provas inegáveis da atividade do filho trombadinha. (MENEZES, 2013, p. 28): "Como fui levando, não sei lhe explicar/ Fui assim levando ele a me levar"; "Eu consolo ele/ Ele me consola/ Boto ele no colo pra ele me ninar". A mãe, nesse caso, "também ela é órfã carente, filha de uma sociedade e de um sistema político-social que já morreram e nem sabem.” (CARVALHO, 1984, p. 119).

"O meu guri” lembra bastante um poema de Manuel Bandeira (1991) ("O menino doente"), que poderia ser uma canção de ninar cantada pela mãe do "guri".

Para que o menino

Durma sossegado,

Sentada a seu lado

A mãezinha canta:

"Dodói, vai-te embora!

"Deixa o meu filhinho.

"Dorme...dorme...meu..."

Morta de fadiga, ela adormeceu.

Então, no ombro dela,

Um vulto de santa,

Na mesma cantiga, 
Na mesma voz dela,

Se debruça e canta:

"Dorme meu amor.

"Dorme, meu benzinho..."

E o menino dorme.

O poema é construído a partir da redondilha maior, métrica preferida pela canção popular, transparecendo-nos um tema folclórico, como podemos ver em seus versos: "Dorme, meu filhinho/ Do meu coração". Nesse poema, que possui uma linha melódica próxima à da canção de ninar, o poeta segue a tradição dessas cantigas, que de um modo genérico, a mãe canta para adormecer o filho e pede ajuda do sobrenatural para mantê-lo dormindo. ${ }^{4}$

O importante, no poema de Bandeira, é manter o filho dormindo, como nos mostram o primeiro e o último versos: "O menino dorme. [...]/ E o menino dorme". Entre estes dois versos desenvolve-se o drama emocional da mãe inteiramente esgotada, como na canção de Chico, "Eu consolo ele/ Ele me consola", assim como no poema de Bandeira, "Dorme...dorme...meu.../Morta de fadiga,/ ela adormeceu", dividindo simetricamente o texto. Tanto no poema de Manuel Bandeira quanto na canção de Chico Buarque, o tema principal é o da relação fraterno-amorosa da mãe com o filho, e o cuidado e proteção que esta tenta ofertar.

Na canção de Chico, a relação se dá também de maneira contrária, na medida em que vemos o menino confortando e protegendo a mãe. Também distante do mundo poético de Bandeira está o contorno social da canção de Chico e o final trágico dado à personagem infantil: sua morte pela polícia. Mesmo com a ingenuidade da mãe ao falar de seu filho, vemos que, após a trajetória curta de um criminoso, ele ainda é uma criança: "Chega estampado, manchete, retrato/ com vendas nos olhos, legenda e as iniciais/ Eu não entendo essa gente, seu moço/ Fazendo alvoroço demais/ O guri no mato, acho que tá rindo/ Acho que tá lindo de papo pro ar". Esses versos representam a imagem da criança morta ("De papo pro ar"), com o agravante de estar localizada no mato, lugar de desova de marginais mortos pela polícia ou por grupos de extermínio. $^{5}$

Um fato importante em "O meu guri" é que o menino de rua, normalmente visto como um ser desprovido de sentimento, é apresentado como alguém sensível e amoroso, que consola e presenteia a sua mãe, dando-lhe inclusive um meio de identificação, rompendo a imagem pejorativa e desumana que caracteriza o menor infrator.

Em "Brejo da cruz", do álbum Chico Buarque, de 1984, o compositor utiliza das representações anteriormente comentadas; no entanto, a criança desvalida representa uma coletividade:

Mas há milhões desses seres

Que se disfarçam tão bem

Que ninguém pergunta

\footnotetext{
${ }^{4}$ Neste poema, acham-se alguns dos principais motivos da poesia de Manuel Bandeira: a criança, a doença, a mãe e as cantigas que sua memória reteve.

${ }^{5}$ No álbum Almanaque, após a letra da canção aparece um desenho de uma ossada.
} 
De onde essa gente vem

É bem provável que Chico Buarque esteja representando o momento dos anos da década de 1980 e 1990, em que ocorre o inchaço das ruas das grandes cidades do Brasil de crianças de rua, fugindo da miséria e da violência doméstica, reencontrada novamente nas ruas.
A novidade
Que tem no Brejo da Cruz
É a criançada
Se alimentar de luz
Alucinados
Meninos ficando azuis
E desencarnando
Lá no Brejo da Cruz
Eletrizados
Cruzam os céus do Brasil
$\mathrm{Na}$ rodoviária
Assumem formas mil
Uns vendem fumo
Tem uns que viram Jesus
Muito sanfoneiro
Cego tocando blues
Uns têm saudade
E dançam maracatus
Uns atiram pedra
Outros passeiam nus
Mas há milhões desses seres
Que se disfarçam tão bem
Que ninguém pergunta
De onde essa gente vem
São jardineiros
Guardas-noturnos, casais
São passageiros
Bombeiros e babás
Já nem se lembram
Que existe um Brejo da Cruz
Que eram crianças
E que comiam luz
São faxineiros
Balançam nas construções
São bilheteiras
Baleiros e garçons
Já nem se lembram
Que existe um Brejo da Cruz
Que eram crianças
E que comiam luz

Há, nesta canção, a presença do espaço social da rodoviária, que encena a representação da migração dos nordestinos fugidos da pobreza para o sudeste do país. Este espaço também revela o trânsito do mundo da infância para o mundo adulto, por meio da observação dos meninos drogados, da vida dos migrantes sobreviventes e entregues a profissões pouco valorizadas e a subempregos: jardineiros, passageiros, bombeiros, babás, faxineiros, pedreiros, 
bilheteiras, baleiros e garçons. O município de Brejo da Cruz, pertencente ao Estado da Paraíba, metonímia da origem dos migrantes, já não é mais lembrada por seus habitantes, imersos em suas vidas corridas e trabalhosas na cidade grande.

Já nem se lembram

Que existe um Brejo da Cruz

Que eram crianças

E que comiam luz

Portanto, o eu lírico, que funciona, na canção, como um observador da vida desses seres "que comiam luz", está evidenciando a perda da origem e da identidade dessas pessoas devido ao massacre social do indivíduo, que o torna invisível. A carência é tanta que se perde até mesmo a identidade, da mesma forma que a mãe de "O meu guri” não tem também a sua: "Um lenço e uma penca de documentos/ Pra finalmente eu me identificar, olha aí".

Essa construção da figura infantil marginal pode ser vista também em "Minha história" (Gesubambino), do álbum Construção, de 1971, canção de Dalla e Pallottino que Chico Buarque traduziu do italiano. ${ }^{6} \mathrm{Na}$ canção, o tema da infância se encontra valorizado em seu grau máximo.

Ele vinha sem muita conversa, sem muito explicar Eu só sei que falava e cheirava e gostava de mar Sei que tinha tatuagem no braço e dourado no dente E minha mãe se entregou a este homem perdidamente

Ele assim como veio partiu não se sabe pra onde E deixou minha mãe com olhar cada dia mais longe Esperando, parada, pregada na pedra do porto Com seu único velho vestido cada dia mais curto

Quando enfim eu nasci minha mãe embrulhou-me num manto Me vestiu como se eu fosse assim uma espécie de santo Mas por não se lembrar de acalantos, a pobre mulher Me ninava cantando cantigas de cabaré

Minha mãe não tardou a alertar toda a vizinhança A mostrar que ali estava bem mais que uma simples criança E não sei bem se por ironia ou se por amor Resolveu me chamar com o nome do Nosso Senhor

Minha história é esse nome que ainda hoje carrego comigo Quando vou bar em bar, viro a mesa, berro, bebo e brigo Os ladrões e as amantes, meus amigos de copo e de cruz Me conhecem só pelo nome de Menino Jesus.

O eu lírico da canção narra sua própria história, de sua infância à vida adulta. A narrativa vai colocar a criança, vinda da mais baixa condição social e moral, e transpô-la para a mais alta

\footnotetext{
6 “O original de Della e Pallottino tinha o subtítulo de 'O filho da guerra', que é como são conhecidas as crianças nascidas de mães solteiras italianas com soldados estrangeiros. [...] A implicante e implacável censura não gostou do título 'Menino Jesus', e o autor o substituiu por 'minha história”'. (HOMEM, 2009, p. 89).
}

Anu. Lit., Florianópolis, v. 23, n. 2, p. 46-66, 2018. ISSNe 2175-7917 
dignidade possível dentro do contexto cristão ocidental. Esta criança, filha de uma prostituta, alcança o status de menino Jesus - já que é dado este nome à criança -, símbolo da mais alta nobreza que o homem já pode chegar: ser filho de Deus.

Chico Buarque eleva o mais baixo, representado aqui pela figura da criança gerada por uma prostituta, ao mais elevado grau de dignidade e nobreza. Mesmo que esta canção não tenha sido escrita por Chico, o fato dele ter feito sua versão mostra a grande identificação do compositor com ela, acoplando-a a seu cancioneiro e, portanto, reforçando o grau de cumplicidade.

Essa criança vive em um meio altamente marginalizado, tanto social quanto moralmente, em meio às prostitutas, ladrões, etc. Enfim, no meio das pessoas mais desqualificadas socialmente. Esse comportamento é valorizado e dignificado na canção que rompe com a moral vigente, que vê estas pessoas como más companhias de forma preconceituosa e excludente. Chico Buarque volta ao sentido primeiro do cristianismo, no qual a solidariedade e o respeito e a própria vida das pessoas simples são valorizadas, e a estas é garantido o reino do céu.

Em “Carioca”, canção do álbum As cidades, de 1998, Chico apresenta, agora, a infância desprotegida por meio de uma personagem feminina.

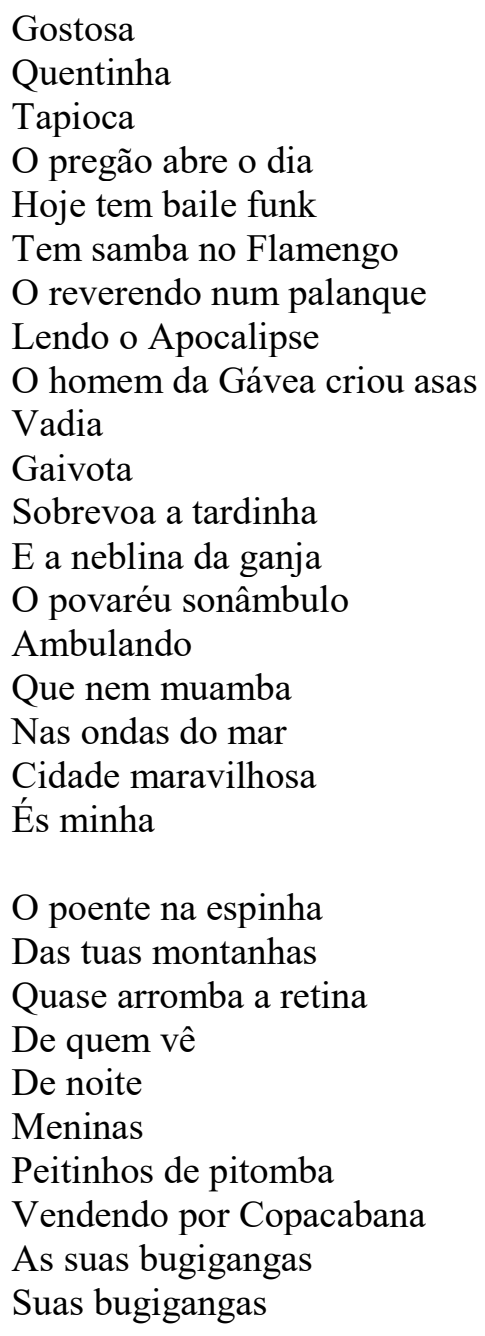


A canção narra o dia a dia da região central das ruas da cidade do Rio de Janeiro, no Largo da Carioca. A agitação da cidade é dada por três aspectos principais: o movimento do comércio e do lazer ("Gostosa / Quentinha / Tapioca / O pregão abre o dia / Hoje tem baile funk / Tem samba no Flamengo"); a pregação religiosa ("O reverendo / No palanque lendo / O Apocalipse") e a expressão da natureza ("O homem da Gávea criou asas / Vadia / Gaivota / Sobrevoa a tardinha / E a neblina da ganja").

No término da canção, a noite cai e um novo mundo se revela, o mundo da prostituição, por meio da figura de uma menina que se vende nas ruas de Copacabana (bairro turístico da cidade, profícuo em guetos de prostituição). Comparada a mercadorias vendidas pelos migrantes nordestinos do centro da cidade, a venda do sexo feminino infantil é como a da tapioca ("gostosa" e "quentinha"), anunciando o pregão noturno que se inicia (com a repetição do início da canção), dando um aspecto de circularidade da canção, temporalmente marcada pelo dia e pela noite, no Largo da Carioca.

Como um comerciante da rua, o eu lírico anuncia as mercadorias, as meninas que se vendem pelas ruas, transformadas em mercadorias baratas. Estas pequenas prostitutas ("meninas") revelam o roubo da infância pela necessidade de sobrevivência na precoce atividade sexual, como revela a metonímia de menina representada pelos seus "peitinhos de pitomba".

\section{Considerações finais}

A criança em grande parte de nossa história foi considerada inferior, débil, fraca, imperfeita. Chico Buarque rompe com este ponto de vista preponderante da nossa sociedade, até quase nos nossos dias, o do adulto, do branco, do civilizado, que reduz à sua própria realidade a realidade dos outros. Como aponta Antonio Candido:

O mundo das crianças, por exemplo, ou dos povos estranhos - sobretudo os chamados primitivos - era passado por este crivo deformante. Quando lembramos que Rousseau discerniu há mais de duzentos anos que o menino não é um adulto em miniatura, mas um ser com problemas peculiares, devendo o adulto esforçar-se por compreendê-lo em função de tais problemas, não dos seus próprios; e que, no entanto, depois de dois séculos a maioria dos brancos, civilizados, continua a tratar os seus filhos e alunos como se esta verdade não estivesse consagrada pelos teóricos e pela observação de todo dia - quando pensamos nisso podemos, comparativamente, avaliar a força da chamada ilusão antropocêntrica. (CANDIDO, 1985, p. 41).

A poética de Chico Buarque propicia a manifestação do infantil, não só por meio de temas, mas também de sua linguagem. O mundo infantil, com sua imaginação, adquire o poder de transformar a realidade em sonho, por meio do lúdico e do encantatório, transfigurado na canção. Chico Buarque vê a infância como um tempo bom, no qual a imaginação e as brincadeiras lúdicas sobrepõem-se ao mundo adulto opressor, rígido e racional. Tal perspectiva pode ser vista em canções como "Até pensei”; “João e Maria"; "Maninha", "Doze anos" e 
"Massarandupió".

Revelando um lado contrário da infância, na qual ela ocupa um lugar de descaso e abandono, aparecem canções como "Pivete"; "O meu guri"; "Minha história"; "Brejo da cruz" e "Carioca". Na maior parte dessas canções, o que se vê é o abuso do mundo infantil, que precisa amadurecer para sua sobrevivência, por meio de sua inserção no mundo marginal, seja roubando, seja se prostituindo, ou no subemprego alienante, que faz o indivíduo perder sua própria identidade. Nesse mundo infantil desprotegido, os sonhos são permitidos apenas em meio a alucinações momentâneas, proporcionadas pelas drogas, ou através do olhar ingênuo da mãe.

\section{Referências}

BANDEIRA, Manuel. Estrela da vida inteira: poesias reunidas e poemas traduzidos. Rio de Janeiro: José Olympio, 1991.

BOSI, Alfredo. O ser e o tempo na poesia. São Paulo: Cultrix; Edusp, 1977.

CANDIDO, Antonio; CASTELO, José Aderaldo. Presença da Literatura Brasileira: das origens ao realismo. Rio de Janeiro: Bertrand Brasil, 1991.

CANDIDO, Antonio. Literatura e Sociedade. São Paulo: Companhia Editora Nacional, 1985.

CARVALHO, Gilberto de. Chico Buarque: análise poético-musical. Rio de Janeiro: Codecri, 1984.

CAVALCANTI, Luciano Marcos Dias. Música popular Brasileira e Poesia: a valorização do "pequeno" em Chico Buarque e Manuel Bandeira. Belém: Paka-Tatu, 2007.

FONTES, Maria Helena Sansão. Sem fantasia: masculino e feminino em Chico Buarque. Rio de Janeiro: Graphia, 1999.

FREUD, Sigmund. O poeta e o fantasiar. In: artistas. Belo Horizonte: Autêntica, 2015, p. 53-66. Sigmund Freud: arte, literatura e os

HOLlANDA, Chico Buarque de. Chapeuzinho Amarelo. Rio de Janeiro, Berlendis \& Vertechia, 1979.

HOLLANDA, Chico Buarque de. Os saltimbancos. Som Livre, 1977.

HOLLANDA, Chico Buarque de; LOBO, Edu. O grande circo místico. Som Livre, 1983.

HOLLANDA, Chico Buarque de. Chico Buarque: letra e música. (Humberto Werneck, org.) São Paulo: Companhia das Letras, 1989. (Songbook)

HOMEM, Wagner. História de canções - Chico Buarque. São Paulo, Leya, 2009.

MENEZES, Adélia Bezerra de. Desenho mágico: poesia e política em Chico Buarque. São Paulo: Hucitec, 1982. 
MENEZES, Adélia Bezerra de. Dois guris - ou a maternidade ferida. In: FERNANDES, Rinaldo de (Org.). Chico Buarque: o poeta das mulheres, dos desvalidos e dos perseguidos. São Paulo: Leya, 2013.

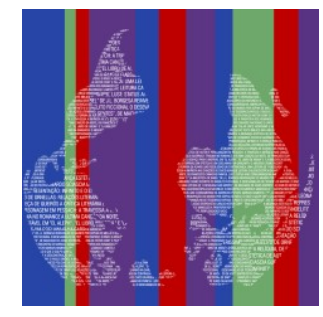

